\section{STONEHENGE.}

The announcement that the fanous and mysterious circles of stones on Salisbury Plain, England, known as "Stonehenge," have been offered for sale gave a new earlier time have al ways exciced. It was feared at first that the property would be purchased and, perhaps, carried away and erected on alien soil. The price named for Stonehenge and for about 1,300 acres of land adjoining was $\$ 62 \tilde{5}, 000$, and up to the present time no purchaser has been found, but it is hoped that the British government will see their way clear to buy this remarkable archæological monument, or at least some patriotic purchaser will buy it and guard it as it de-

'T he English Illustrated Magazine recently had an illustrated article dealing with the subject with photo graphs taken from new points of view, and from this we glean our facts. Like all standing stones, Stonehenge is, of course, a mystery, and all solutions of this eternal riddle must at best be guesses. The name is a corruption of the Saxon Stan-hengist, the uplifted or hanging stones; and this has, no doubt, given rise to the legend of enlargement and alteration by the British King Ambrosius, aided by Merlin, during the period of Hengist. Although absolute truth is impossible, the views of antiquaries concerning the origin of Stonehenge are worth considering. Some attribute the circles to the Phœnicians, or at least to Phœnician influence, and connect them with Baal-worship; others favor the familiar theory of Celtic or Druidical origin. The remains have also been ascribed to the Danes and Romans. The opinions as to its age are legion, some Romans. The opinions as to its age are legion, some
holding that the circles must have been formed in the century before the Christian era, others placing them as late as $500 \mathrm{~A} . \mathrm{D}$. The old puzzle as to the mechanical power employed is here, of course, particularly in sistent on account of the ponderous cross pieces of the trilithons. It is safe to conclude that the stones of the inner circle and inner oval have been brought from a distance, and are of earlier origin than the others. Among more recent theories as to the origin of Stone henge is that of Sir John Lubbock, who inclines to the opinion that the circles were erected during the
bronze age in Britain. It is, however, not improbable that various portions of the monument should be assigned to various dates.

The main features of Stonehenge are a "Via Sacra," or "Holy Way," two concentric circles of upright stones, two elliptical groups of stones, known as the reat and little, a circular embankment, and at a con siderable distance from these an isolated monolith, upon which tradition has bestowed the familiar name
of the "Friar's Heel." The "Via Sacra" is an avenue 1.782 feet long and has the appearance merely of a long earthen embankment of inconsiderable elevation. At one time it was at least 15 feet high, and was defended by an intrenchment. The entire circuit of this mound measures 1,009 feet. Proceeding inward from the circular mound for a distance of 120 feet, the visitor reaches the outer circle of the group. This at one reaches the outer circle of the group. This at one
time consisted of thirty upright stones, $31 / 2$ feet apart, rising to the height of 16 feet, coupled by horizontal imposts so as to form trilithons. A rude mortise and tenon arrangement held them together. Of this circle there remain now only sixteen uprights and six crosspieces. Nine feet within the outer circle are the remains of the sacred ring, containing now only seven upright monoliths. Within the second circle again is the remnant of what had been the most magnificent portion of Stonehenge, the first ellipse. Of these original five or seven trilithons there remain only two and two single uprights ; these, however, reaching at their utmost the height of 21 feet, and nowhere less than 16 feet-16 feet also being the length of the imposts. These are sufficient to show the ancient grandeur of the first ellipse. The second was originally cousposed of nineteen uprights, of which only six remain. Within these is the so-called altar-stone, a flat rock 15 feet long. The Friar's Heel stands isolated at a distance of 120 feet from the circular embankment and 240 feet from the innermost stone circle, the emFriar's Heel and the first circle. It is a huge irregular block 16 feet high, and is in a leaning position. Those who favor the Phœnician theory find in this monolith who favor the Phœnician theory find in this inonolith gnomon or pointer of the rising of the summer sun. Whatever may have been its uses, Stonehenge remains for us a most fascinating riddle.

\section{THE "GREEN RAY" AT SUNSET}

The "green ras" or "green flash" at the moment the sun disappears from view beneath the horizon has been noticed by many physicists. Some of them consider this is an optical illusion. M. Guebhard states, however, that the green ray is the great shadow of the by an eye fatigued for red; it therefore appears green. Pellat on the contrary states that the "yellow setting sun has a red lower and green upper border separately examinable in the telescope and due to prismatic re flection by the atmosphere. The absorption which makes the sun disk appear yellow makes the violet upper rin appear green or greenish blue instead o violet. When the sun sets, the upper green rim can be seen for a fraction of a second, but it may be kept onger in view if the observer goes up a slope as the thought this was different from the green ray following the setting of the red sun. M. Raveau said that he had seen the sea colored green in a triangie with its apex at the point where the sun set, and the colo seems to flow away toward the horizon.

\section{THE NEW MINING DISTRICT AT CAPE NOME.}

BY ENOS BRown.
The latest vessel to leave Cape Nome, Alaska, arrived in port a few days ago bearing the last of the discoverers and a million dollars in gold dust.

Cape Nome has absorbed the attention of all those whose confidence in the future of Alaska as the greatest gold-producing country in the world has not been impaired by a want of success in the inhospitable in terior regions of which Dawson is the great center. The American miners, driven out of the territories controlled by the Canadians, have been industriously prospecting along the coast, finding traces of gold almost everywhere. Rumors of the rich discoveries a Cape Nome have been abroad for over a year past, contradicted at times by those, interested in keeping the knowledge of the real facts from the rest of the world. From private sources and from the occasiona visits of the adventurous, information of the remarkable richness of the country has been disseminated in the West until the tide of travel and investigation turned toward the point and invaded the camp by thousands. In August, the population of Nome Cit amounted to 7,000 men, and in the country roun about to at least 3,000 more. A city has grown up in a month, and though a very large proportion of the prospectors have left the country at the approach of rigors of the climate and remain until the advent of rigors of the climate and remain unt
summer permits a resumption of work.

The output of the Cape Nome mining region for the past summer amounts to $\$ 2,500,000$, all from placer and with the aid of the most unscientific appliances. All of the peninsula on Norton Sound, from Norton Bay to Cape Prince of Wales, appears to be gold bearing. Within an area fifty miles east and west of been discovered. Back toward the range which separates Norton from Kotzebue Sound, many gulche have been prospected and the most hopeful indication discovered. Where these gulches have been mined, i the immediate vicinity of Nome, the yield of gold has been astonishing. Taking into consideration the ex tent of country and its known richness, together with the comparatively easy methods required for extrac tion of the gold, it is the opinion of men, not the most enthusiastic, that in 1900 Cape Nome will produce more gold than all the rest of Alaska, Klondike in cluded, put together. The new fields have the immense advantage of easy accessibility. From wester ports to the beach at Cape Nome means only a comfortable voyage by steam or sail. There are no dan gerous passes to cross or expensive outfits to purchase. world. Under these conditions it is anticipated that world. Under these conditions it is anticipated that of myriads of people that the world has ever known toward these new mines.

Cape Nome is situated in about the 64th degree of latitude, 120 miles north of St. Michaels and about 3 degrees south of the Arctic circle. The seasons ar vegetables can be grown there. Snow and ice disappear about the middle of May, and until the early part of October the climate is comparatively mild. Four and one-half months of work a season is the average. Ic begins to accumulate in the sea in October, and pile up in great hummocks during the winter season. The cold sometimes reaches 60 degrees below. In summer there is much rain and fog. The first placers were found on the beach in a strata of ruby sand, generally four inches in depth, and sometimes two or three are four inches in depth, and sometimes two or three ar five hundred men were working on the beach and were averaging an ounce a day each. The theory ha been that the gold thus mined is washed up by th sea. The origin is not as yet certainly known.

In the gulches the bed rock, as far as known, averages not deeper than five feet from the surface. Where worked, the yield of the gulches has been very large. Whatever the outcome of Cape Nome, it will ever be associated with the discovery of a new word in mining phraseology, "tundra," which is aborigine, and describes the low, marshy land lying between the beach and the foothills, having a width at Cape Nome of five seacoast lands.

Travelers in Alaska all refer to the moss-covered soils saturated with moisture. abounding in great areas in the valleys and forests; a sort of spongy blanket on

top of the ground, generally frozen underneath. At Cape Nome, extending from the sea beach back to the foothills, a distance of about five miles, and extending with moss. This is well defined and characteristic of
withen the country, and is called by the Indians "tundra." Its depth at Cape Nome is three feet, and underneath, every where in fact, rich deposits of gold are found.

\title{
JOHN RUSKIN.
}

John Ruskin died at Rrantwood, Conistan Water, England, on January 20. He was born in the heart of London, in 1819, his father being a wealthy wine merchant. He was writing for the press before he was sixteen, and he graduated from Oxford in 1842 . He sixteen, and he graduated from Oxford in 1842 . He
studied art for a year and then wrote a most remarkable book entitled "Modern Painters," which brought him fame and a storm of abuse. He soon became noted as a great master of words, and he began recling off book after book on art and scientific subjects. He was Slade Professor of Fine Arts at Oxford for many years. He was one of the chief pioneers in the PreRaphaelite movement, and also paid great attention to economic and social problems. His "Stones of Venice" is probably his most widely read book.

In the death of John Ruskin the world has lost one of its greatest thinkers and one of the masters of English. His death had been expected for some time, and it is doubtful if it has created anything like the interest which it would have done some thirty years ago. He was one of those unfortunate writers who outlive their own reputation. He will never be forgotton, but his place in literature has been steadily declining for the last twenty years. His writings are injured by a bilious temperament, which resulted in outbursts of wrath upon the smallest occasion, and the views of Ruskin in most cases were diametrically opposed to modern progress ; and while he storms at machinery, railways and steamboats and other things which enable us to carry on our existence in a comfortable and economical manner, his diatribes are always entertaining. His magnificent prose full of Oriental imagery is 2 lesson to all writers. 'The value of Ruskin's art writings is not very great at the present time, but he opened the eyes of a Philistine generation to the beauty of Art, and for this alone we should never cease to thank him. He told people what to see and how to
see it. They saw with their own eyes, and abandoned his conclusions and deductions, which were usually based on wrong a priori premises. The result has been that as an advocate of art he is revered, but as a special pleader he is seen at his worst.

His ideas on art education are all wrong and his theories do not stand the test of logic. His views on geology, botany, social science and political economy, while pleasing and clothed superbly with an elegance almost valueless. The artist repudiates his art system, the geologist his geological writings, and the political ecoromist laughs at the absurd theories which would set us back three hundred years. One writer has said that "he literally got to the bottom of nothing;" with all his immense enthusiasm for science and art, he was superficial. His later life was saddened by a cerebral disorder the gradual increase of which strengthened the view which many held that his genius was closely akin to madness. He was not even consistent, for while he was spending thousands of pounds on the workingman and preaching from every lecture plat. form and urging men to read his gospel of life, he published his works in such a manner that they were very expensive, and his profits from this alone must have he wondered why people doubted his sincerity.

\section{CROPS IN 1899.}

The statistician of the Department of Agriculture has made public his estimates of the acreage production in value of the crops of 1899 . The wheat acreage was $44,592,516$, producing $547,303,846$ bushels, having a value of $\$ 319,545,259$, the average yield being 123 bushels, the average farm price per bushel being 58.4 $2,078,143,933$ bushels, the value being $\$ 692,210,110$, the avarage yield per acre being 25.3 bushels, and the avarage yield per acre being 25.3 bushels, and the
average price 30.3 cents. The acreage in oats was average price 303 cents. The acreage in oats was
$26,341,380$, the production was $786,177,713$ bushels, and the value $\$ 198,167,975$, the average yield per acre $30 \cdot 2$ bushels, and the average price $24 \cdot 9$ cents. The barley crop is estimated at $73,381,563$ bushels ; the rye crop bushels, and the hay crop at $156,653,756$ tons.

\section{DEATH OF PROF. HUGHES.}

Prof. David Edward Hughes, inventor of the Hughes printing telegraph instrument, which is now in use on all important continental lines in Europe, and all submarine lines between England and the Continent. died on January 23. in England, at the age of sixty-nine.
He was the discoverer of the microphone now used almost everywhere as a transmitter for the telephone. He was also the. inventor of the induction balance, a most interesting scientific instrument. 